\title{
МЕДИАОБРАЗОВАНИЕ В ЗАРУБЕЖНЫХ СТРАНАХ
}

\author{
В. А. Прокопов \\ Российский экономический университет им. Г. В. Плеханова
}

\begin{abstract}
Аннотация: Статья посвящена изучению системы медиаобразования в зарубежных странах. В условиях интенсивного развития цифровых технологий, увеличения влияния медиа и внедрения медиаобразовательных практик в учебные заведения автор уделяет внимание целям, задачам и особенностям медиаобразовательных систем Великобритании, США и Франции, а также необходимости развития медиаграмотности и медиакомпетентности среди детей и молодежи.

Текст доклада автора на XV Международной научной конференции «Высшее образование для ХХІ века. Роль гуманитарного образования в контексте технологических и социокультурных изменений», которая прошла 14-16 ноября 2019 года в Московском гуманитарном университете.
\end{abstract}

Ключевые слова: медиаобразование; медиакомпетентность; медиаграмотность; критическое мышление; медиатизация образования

\section{MEDIA EDUCATION IN FOREIGN COUNTRIES}

\author{
V. A. Prokopov \\ Plekhanov Russian University of Economics
}

Abstract: The paper studies the system of media education in foreign countries. In the context of intensive development of digital technologies, increasing influence of media and the introduction of media educational practices in universities, the author pays attention to the objectives, tasks and features of media education systems in Great Britain, the USA and France. He also points out the need to develop media literacy and media competency among children and young people.

The text of the author's speech at the 15th International Scientific Conference "Higher Education for the 21st Century. The Role of Education in Humanities in the Contest of Technological and Sociocultural Changes" held at Moscow University for the Humanities on 14-16 November 2019.

Keywords: media education; media competency; media literacy; critical thinking; mediatisation of education

\section{Введение}

В XXI веке ключевым товаром выступает информация. Появление глобальной сети позволяет человеку с огромной скоростью преодолевать политические и географические границы. Сегодня множество различных ценностей и культур доступны для созерцания каждому человеку. Ежедневно люди обращаются к медиатехнологиям. Это может являться следствием ка- 
кой-либо профессиональной деятельности специалистов любого профили или же просто досуговым времяпровождением. Однако в медиасфере существуют риски, связанные с неумением правильно пользоваться информационными технологиями (под угрозу попадают персональные данные пользователя). Кроме того, еще одной из проблем является неумение огородить себя от «вредоносного» контента. Поэтому возникает необходимость в умении правильно себя вести в цифровой среде, то есть обладать определенной медиаграмотностью. Для этого начали активно внедряться образовательные программы, направленные на формирование медиаграмотности. С каждым днем медиаобразование развивается все более интенсивно. Сегодня образовательные системы различных стран в условиях глобализации интегрируются и производят обмен образовательными практиками. Проводится большое количество конференций, симпозиумов, круглых столов, посвященных проблематике медиаобразования.

Для успешного развития медиаобразовательных практик в современной России необходимо обратиться к опыту зарубежных стран, в частности Великобритании, США и Франции.

\section{Медиаобразовательные практики в Великобритании}

Великобритания одна из первых западноевропейских стран, которая активно повышала медиаграмотность своих граждан. Медиаобразование стало неотъемлемой частью учебной программы на каждой ступени школьного обучения (Михалева, 2015).

Личность в Великобритании сегодня развивается на основе и с помощью материалов СМК. Таким образом, формируется культура коммуникации с медиа, критическое мышление, умение интерпретировать, анализировать и оценивать медиатексты. Кроме того, происходит обучение в области позиционирования и самовыражения посредством СМК.

Ключевыми задачами в развитии медиаграмотности детей и молодежи в Великобритании являются формирование критического мышления в отношении медиа, поощрение творчества школьников и молодежи в медиасреде, а также расширение социокультурного опыта молодежи в медийной сфере.

Между тем, большое количество британских педагогов и преподавателей опасаются, что СМК могут нанести моральный ущерб ребенку. Кроме того, в последнее время в британских исследованиях было выявлено, что СМК оказывают влияние на стратегии поведения, физическое и моральное состояние молодых людей, формируются устойчивые стереотипы мышления, предвзятое мнение к тем или иным событиям, транслируемым в СМИ. Исследователи приводят следующие характеристики: «изменение формы поведения, в частности, как растущую склонность причинять зло окружа- 
ющим людям (например, агрессия, тактика запугивания, расизм, преследование) или себе (например, анорексия, заниженная самооценка, суицид)» (Livingstone, Haddon, 2009: Электр. ресурс).

Сам ущерб проявляется в таких факторах, как стрессы, депрессия, непонимание среди сверстников, что ведет к потере дружеских контактов. Нередко среди молодых людей наблюдается устойчивый образ недооцененного молодого человека, подверженного постоянным расстройствам.

Главным принципом британской модели медиаобразования можно назвать демократичный и диалоговый характер. То есть, создается огромное количество учебных и внеучебных программ, направленных на изучение медиасреды, педагоги имеют большое количество форм и методов в реализации учебного процесса, кроме того, изучаются различные виды медиа (Интернет, печатные медиа, аудиовизуальные и т. д.). Весь процесс построен на уважительном сотрудническом отношении к учащимся. Согласно официальной статистике около 33\% выпускников британских школ в возрасте 18 лет (т. е. около 400 000) поступают в вузы, при этом число курсов по изучению медиа и медиакультуры на получение ученой степени составляет около 9313 (там же).

Несмотря на то, что британская модель является одной из ведущих в мире, у нее есть свои недостатки. В условиях, когда технологии видоизменяются и прогрессируют с каждым днем, появляется дефицит медиапреподавателей. Кроме того, и в школах, и в университетах выделено небольшое количество часов на изучение медиакультуры, а также само медиаобразование все еще не носит обязательного характера (Михалева, 2013).

Таким образом, британская система медиаобразования характеризуется максимизацией возможностей личности (в образовательной, информационной, профессиональной сферах, а также в реализации собственного творческого потенциала) и минимизацией рисков, связанных с манипуляцией, эмоциональным ущербом и т. д.

\section{Медиаобразование в США}

Несомненно, США является одним из главных лидеров в области медиакультуры. Долгое время медиаобразование США уступало позиции британской, канадской и австралийской системам медиаобразование. Однако с начала 90-ых годов большое количество университетов стали уделять внимание этой и сфере. Изучение медиакультуры начиналось на факультативных занятиях. Стали появляться образовательные центры, специализирующиеся на медиаобразовании.

В 2007 г. Национальной ассоциацией медиаобразования (National Association for Media Literacy Education - NAMLE) были выделены шесть основных принципов медиаобразования: 
1. Медиакультура американцев должна основываться на медиакомпетентности и медиаграмотности. Необходимо было активно изучать медиасреду, а также вырабатывать критическое мышление по отношению ко всем получаемым месседжам;

2. Медиаобразование должно осуществляться не только в школе, но и в различных внешкольных программах, а также в колледжах, университетах, факультативных занятиях на дому, а также онлайн;

3. Главной задачей медиапедагогов является расширение методик и возможностей при медиаобразовании (диалоговый принцип образования);

4. Медиаобразование способствует подготовке компетентных, мыслящих и неравнодушных членов демократического общества;

5. Школьникам и студентам разрешено изучать альтернативные точки зрения при изучении медиатекстов;

6. Особенность современной медиасреды заключается в том, что мы можем быть не только потребителями текстов и информации, но и их производителями. Для этого школьникам и молодежи необходимо опираться на собственный опыт, умения и убеждения. Американское медиаобразование допускает тот факт, что интерпретация того или иного текста студентом может отличаться от интерпретаций преподавателя (NAMLE, 2007: Электр. ресурс).

Однако многие эксперты высказывают мнение, что в США не уделяют должного внимания сфере образования. США является лидером-экспортером медиапродуктов, однако они все равно отстают от других англоязычных стран в системе медиаобразования.

Р. Кьюби исследовал причины отставания США в области медиаобразования с культурной, экономической, исторической и политической точек зрения. Он выделил четыре препятствия на пути развития медиаобразования: обширные территории, культурные различия, недостаток стимула и различные теоретические парадигмы (Сердюков, 2011: Электр. ресурс).

1. Кьюби предполагает, что значительная разобщенность неизбежна (в каждом штате свои органы управления и законы в сфере образования);

2. В США, в отличии от других англоязычных стран, очень сложно прийти к согласию и слаженности действиях в вопросах, связанных с системой образования;

3. СМИ в США не являются движущей силой в развитии медиаобразования (в отличии от Великобратиании);

4. В США отсутствует общая теоретическая медиаобразовательная парадигма, которая могла бы дать стимул и наметить общий курс развития такого направления в педагогике, как медиаобразование (Федоров, 2010).

Большую роль в сфере медиаобразования США стали приобретать не- 
Научные труды Московского гуманитарного университета 2020 № 1

коммерческие ассоциации, которые не могут прийти к единой методике обучения для развития медиобразования США. Тем не менее, ассоциации занимаются повышением квалификации преподавателей и педагогов, проводят крупные исследования в этой сфере, сотрудничают с коллегами из других (в основном англоязычных) стран, предлагают новые программы обучения в области медиаобразования.

В отличии от британской системы в США не уделяют большого внимания рискам, с которыми могут столкнуться молодые люди (там же). Это может привести к тому, что школьники и молодежь будут менее эмоционально и психологически устойчивы.

Таким образом, несмотря на определенные недостатки, американское медаобразование все равно занимает лидирующие позиции в мире, сфера продолжает активно развиваться.

\section{Медиапедагогика во Франции}

Особенность медиаобразовательной системы во Франции заключается в том, что удельный вес имеют медиаобразовательные центры. Одним из самых крупных медиаобразовательных центров во Франции является CLEMI - Centre de liaison de l'enseignement et des medias d'information. http:// www.clemi.org. Во Франции, как и в Великобритании, большое внимание уделяется развитию медиаграмотности и медиакомпетентнсти. Критическое мышление у школьников и молодежи формируется на основе работы с медиатекстами, ведется активная работа с СМК. Кроме того, важной задачей является преодоление изоляции школы от медиа, чтобы формировать гражданина в условиях жизненных реалий.

CLEMI занимается повышением уровня медиакомпетентности, проводит конференции и лекции не только на национальном уровне, но и на наднациональном. Кроме того, CLEMI активно сотрудничает с ЮНЕСКО.

Главными задачами французской системы медиаобразования являются: формирование критического и демократического мышления на основе медийных материалов, а также развитие навыка грамотного анализа медиатекстов разных жанров. Как и в вышеописанных системах во Франции молодой человек является не только медиапотребителем, но и медиапроизводителем, поэтому проводится большая работа с молодым поколением для грамотного создания медиаматериалов (школьная и студенческая пресса, популярные видеоблоги, создание собственных сайтов в Интернете и т. д.).

Таким образом, в сфере медиаобразования во Франции уделяется большое внимание (как в США) различным медиаобразовательным центрам, однако учебный процесс с детьми и молодежью осуществляется на основе работы с медиатекстами СМК (как в Великобритании). Кроме того, важное 
место уделяется работе именно со школьниками младшей школы (создаются специальные центры для работы с детьми в медиасфере).

\section{Выводы}

Таким образом, можно заключить, что медиаобразование активно развивается. Более того, это достаточно гибкая система, которая достаточно быстро эволюционирует. Сравнительный анализ медиаобразовательных практик зарубежных стран показал, что главной целью медиаобразования является формирование у детей и молодежи медиаграмотности и медиакомпетентности. Это выражается в формировании критического и демократического мышления на основе медийных материалов. Кроме того, детям и молодежи разрешено быть не только медиапотребителями, но и медиапроизводителями при грамотной и логичной работе с медиаматериалами. Зарубежное медиаобразование характеризуется демократическим и диалоговым характером (учет мнения школьников и студентов). Несмотря на это, системы по-прежнему не совершены. Во всех странах медиаобразование не является обязательным (если не учитывать профильные направления), кроме того, все еще не хватает квалифицированных специалистов, способных работать в медиапедагогике. Критический подход к обзору медиаобразовательных практик зарубежных стран дает возможность в развитии российской медиаобразовательной сферы.

\section{СПИСОК ЛИТЕРАТУРЫ}

Михалева, Г. В. (2013) Социокультурные и теоретико-методологические основы современного медиаобразования в Великобритании // Медиаобразование. № 4.

Михалева, Г. В. (2015) Медиаобразование в Великобритании: история и современность. Таганрог : Изд-во ЮФУ. 224 с.

Сердюков, Р. В. (2011) Медиаобразование в США в XXI веке [Электронный ресурс] // Педагогика искусства. № 2ю URL: http://www.art-education. ru/electronic-journal/mediaobrazovanie-v-ssha-v-xxi-veke (дата обращения: 17.10.19).

Федоров, А. В. (2010) Словарь терминов по медиаобразованию, медиапедагогике, медиаграмотности, медиакомпетентности. Таганрог : Изд-во Таганрог. гос. пед. ин-та. 48 с.

Livingstone, S., Haddon, L. (2009) Young People in the European Digital Media Landscape: A Statistical Overview with an Introduction. The International Clearinghouse on Children, Youth and Media [Электронный ресурс] // NORDICOM University of Gothenburg. URL: https://www.nordicom.gu.se/sites/default/files/ publikationer-hela-pdf/390_young_people_in_the_nordic_digital_media_culture. pdf (дата обращения: 17.10.19). 
NAMLE (2007): Core Principles of Media Literacy Education in the United States [Электронный ресурс] // http://www.namle.net/core-principles/namlecpmle-w-questions.pdf (дата обращения: 17.10.19)

Дата поступления: 17.10.2019 г.

Прокопов Владислав Андреевич - студент кафедры политологии и социологии Российского экономического университета им. Г. В. Плеханова. Адрес: 119501, Россия, г. Москва, ул. Матвеевская д. 4. к. 1. Тел.: +7 (903) 71161-61. Эл. адрес: prokopov_vlad@mail.ru

Prokopov Vladislav Andreyevich, Student, Department of Politology and Sociology, Plekhanov Russian University of Economics. Postal address: 4, Bldg. 1, Matveyevskaya St., Moscow, Russian Federation, 119501. Tel.: +7 (903) 711-6161. E-mail: prokopov_vlad@mail.ru

\section{Для цитирования:}

Прокопов В. А. Медиаобразование в зарубежных странах [Электронный ресурс] // Научные труды Московского гуманитарного университета. 2020. № 1. URL: http:// journals.mosgu.ru/trudy/article/view/1123 (дата обращения: дд.мм.гг.). DOI: 10.17805/ trudy.2020.1.4 